\title{
HISTOPATHOLOGICAL PATTERNS OF LESIONS CAUSED BY TWO DICHORHAVIRUS
}

\author{
João Paulo Rodrigues Marques ${ }^{1}$, Aline Daniele Tassi ${ }^{2}$, Gustavo Mortean Filippi ${ }^{3}$, Renato \\ Salaroli ${ }^{3}$, Elliot Watanabe Kitajima ${ }^{3}$
}

\footnotetext{
${ }^{1}$ Center for Nuclear Energy in Agriculture, Piracicaba, Brazil. E-mail: joaoanatomia @ gmail.com

${ }^{2}$ Biological Institute of São Paulo, São Paulo, Brazil. E-mail: alinetassi@ gmail.com

${ }^{3}$ University of São Paulo, Piracicaba, Brazil. E-mail: gustavo.filippi@usp.br, resalaroli@usp.br, ewkitaji@usp.br
}

\begin{abstract}
Different from most plant viruses, Brevipalpus mite-transmitted viruses (BTV) cause localized infection, not being able to systemically invade the infected plant. To broaden the specter of the histopathological changes in leaf tissues induced by BTV infection, we examined the tissue organization of leaf lesions caused by the infection of two additional representatives of dichorhaviruses, Clerodendrum chlorotic spot virus (ClCSV) and Coffee ringspot virus (CoRSV). In general, tissue alterations within the lesions followed the pattern noticed in Citrus leprosis virus CiLV-C and CiLV-N infection. In all analyzed lesions, necrotic cells form the central region that is surrounded by a chlorotic halo where hypertrophied cells commonly occur. Presence of reactive oxygen components were also a characteristic of the chlorotic halo. Though more cases of localized lesions on leaves infected by more BTV remains to be analyzed, it seems that these lesions respond similarly upon infection by BTV, either Cile- or Dichorhavirus.
\end{abstract}

Keywords: Brevipalpus spp., hypertrophy, plant anatomy, plant virology

\section{PADRÕES HISTOPATOLÓGICOS DE LESÕES CAUSADAS POR DOIS TIPOS DE DICHORAVÍRUS}

\section{RESUMO}

Diferente da maioria dos vírus de plantas, os vírus transmitidos pelo ácaro Brevipalpus (VTB) causam infecção localizada, e não invadem sistemicamente a planta infectada. Para ampliar o entendimento do espectro das alterações histopatológicas em tecidos foliares induzidas pela infecção por VTB, examinamos a organização do tecido das lesões foliares causadas pela infecção 
de dois representantes adicionais de dichorhavirus, Clerodendrum chlorotic spot virus (CICSV) e Coffee ringspot virus (CoRSV). Em geral, as alterações teciduais dentro das lesões seguiram o padrão observado na infecção por Citrus leprosis virus CiLV-C e CiLV-N. Em todas as lesões analisadas, as células necróticas formam a região central que é circundada por um halo clorótico onde comumente ocorrem as células hipertrofiadas. A presença de espécies reativas de oxigênio também foi uma característica do halo clorótico. Embora mais casos de lesões localizadas em folhas infectadas por VTB ainda devam ser analisados, parece que essas lesões respondem de forma semelhante à infecção por Cile- ou Dichorhavirus.

Palavras-chave: Brevipalpus spp., hipertrofia, anatomia vegetal, virologia vegetal

\section{INTRODUCTION}

Viruses transmitted by mites of the genus Brevipalpus (Tenuipalpidae) (BTV), known as flat mites or false spider mites, have the peculiarity that their infection consistently results in localized lesions (ring-, necrotic-, chlorotic-spots) on leaves, branches, flowers, and fruits, without systemic spread of the infection (KITAJIMA et al., 2003a, 2010).

The most studied virus in this group is citrus leprosis, first reported in Florida, USA, at the turn of the $20^{\text {th }}$ century (FAWCETT, 1911). However, its relationship with Brevipalpus was only reported in 1940 (FREZZI, 1940). Leprosis is no longer found in the USA, but it is present in the Americas, from Argentina to Mexico, associated with economic losses. In the state of São Paulo, Brazil, the largest orange juice producer in the world, leprosis is considered one of the most economically important diseases, which have been under control by intensive use of chemical control (BASTIANEL et al., 2010). Recently, however, outbreaks of leprosis have been noticed associated with the changes in the citrus culture management after the introduction of the bacterial disease, greening (huanglongbing - HLB) (BASSANEZI, 2018).

BVTs can be divided into 2 groups based on their cytopathology and molecular organization: cytoplasmic type (BTV-C) and nuclear type (BTV-N). BTV-C have short, membrane-bounded, bacilliform particles $(70-80 \mathrm{~nm} \times 100-120 \mathrm{~nm}$ ) that accumulate in cisternae of the endoplasmic reticulum, and produce a dense and vacuolated mass (viroplasm). Their genome consists of bisegmented ( 5 and $9 \mathrm{~kb}$ ) (+) sense, ssRNA, and belongs to the genus Cilevirus, 
Kitaviridae (KITAJIMA et al., 2003; LOCALI-FABRIS et al., 2011; FREITAS-ASTÚA et al., 2018)

BTV-N, on the other hand, have short rod-shaped particles, usually without an enveloping membrane, present in the nucleus and/or cytoplasm, and their infection results in an electron lucent viroplasm the nucleus (KITAJIMA et al., 2003). The genome of BTV-N consists in bisegmented (2 pieces of $6 \mathrm{~kb}$ ) (-) sense, ssRNA. Genomic organization placed them among the family Rhabdoviridae, in a new genus Dichorhavirus (DIETZGEN et al., 2014; 2018). It should be mentioned that the above referred to as leprosis on citrus, is actually a multi-etiological syndrome which can be induced by different viruses, the most important and widespread being citrus leprosis virus C (CiLV-C, Cilevirus) (BASTIANEL et al., 2010; RAMOS-GONZÁLEZ et al., 2018a). Another cilevirus, citrus leprosis virus C2 (CiLV-C2, Cilevirus) is spreading in Colombia (ROY et al., 2013). Isolates of Orchid fleck virus (OFV, Dichorhavirus) causing leprosis was found in Citrus spp. in Mexico (ROY et al., 2015) and recently, for the first time out of the Americas, in South Africa (COOK et al., 2019). In Brazil, the dichorhaviruses citrus leprosis virus N (CiLV-N) and citrus chlorotic spot virus (CiCSV) were found infecting orange [Citrus sinensis (L.) Osbeck] causing leprosis symptoms (RAMOS-GONZÁLEZ et al., 2017; CHABI-JESUS et al., 2018).

Studies of pathosystems involving BTVs that has received little attention is the histopathology of the injuries caused by them in susceptible hosts. Typical lesions of BTV are located and associated with areas of viral replication. From small initial spots of ca. $1 \mathrm{~mm}$ in diameter, usually chlorotic, which appears about 2-4 weeks after the initial infection by the virus inoculated during feeding, by the viruliferous mite, the lesions grow slowly, usually reaching 2-3 $\mathrm{cm}$ in diameter after 2-3 months. The virus, however, does not become systemic and thus does not move to other parts of the plant, as in most plant viruses. This fact probably stems from the BTV inability to invade phloem tissues demonstrated by ultrastructural and immunohistochemical studies (KITAJIMA et al., 2003; CALEGARIO et al., 2011). The few available studies describe histopathological changes made on leaf lesions caused by citrus leprosis virus $\mathrm{C}$ and citrus leprosis $\mathrm{N}$ dichorhavirus (APEZZATTO-DA-GLORIA et al., 2007; MARQUES et al. 2007; 2010). It has been shown that along with the lesions there is a gradient of tissue changes: in the inner region of the lesion, the cells of the spongy and palisade parenchyma have hypertrophied and hyperplasic ells. In the vascular tissue, deposition of mucilaginous material can occur with the xylem and hypertrophy of the cells in the sheath of the vascular bundle. The authors also demonstrate that in 
the region of the most external necrotic halos, cell lysis and the concomitant necrosis of the palisade parenchyma reach the vascular bundles, causing them to collapse. A common character in citrus leprosis, for both nuclear and cytoplasmic, is that the chlorotic border of the mature lesion, next to still uninfected tissues, mesophyll cells are usually plasmolyzed (MARQUES et al., 2010). Using immunofluorescence techniques, the distribution of the antigen (p29 protein, putative nucleocapsidal) was observed in the lesions caused by CiLV-C on an orange leaf. While in young lesions most of epidermal and mesophyll parenchyma cells contain viral antigens, in mature lesions these antigens are randomly scattered with a gradient towards the lesion border (CALEGARIO et al., 2011).

Presently, five species are recognized in the Dichorhavirus genus: Orchid fleck virus (OFV), Coffee ringspot virus (CoRSV), Citrus leprosis $N$ virus (CiLV-N), Citrus chlorotic spot virus (CiCSV), and Clerodendrum chlorotic spot virus (ClCSV) (DIETZGEN et al., 2018). Detailed histopathological information of dichorhavirus-induced leaf lesions is available only for CiLV-N (MARQUES et al., 2010), though brief report on anatomical aspects of ClCSV- and CoRSV-induced lesions have been published (CHAGAS, 1978; GOMES et al., 2010). In the present report, a more thorough analysis of the changes in lesions of ClCSV and CoRSV are described.

\section{MATERIAL AND METHODS}

\section{Plant material}

Bleeding glory bower (Clerodendrum thomsoniae Balf., family Lamiaceae) leaves with characteristic chlorotic spots caused by ClCSV infection (Figure 2A) were collected from a plant experimentally mite-infected, under greenhouse conditions (Department of Plant Pathology and Nematology, Luiz de Queiroz College of Agriculture, University of São Paulo, campus PiracicabaSP). Coffea arabica L. (family Rubiaceae), exhibiting typical ringspot symptoms of CoRSV infection (Figure 3A) were collected in a germplasm nursery collection of Agronomic Institute of Campinas (Campinas, state of São Paulo, Brazil). Control, uninfected leaves of both species were collected and processed as the infected ones, as controls.

The anatomy of healthy plants (controls) and infected plants was determined from light microscopy analysis by selecting three healthy leaves and three symptomatic leaves. The presence of the causal viruses (ClCSV and CoRSV) in examined samples was previously determined by RT- 
PCR using primers specific for CICSV (RAMOS-GONZÁLEZ et al., 2018b) and CoRSV (KITAJIMA et al., 2011).

\section{Light microscopy}

Fragments of leaf tissues from lesions and uninfected of bleeding glory bower and coffee were fixed in a mixture of glutaraldehyde $(2 \%)$ and paraformaldehyde $(2.5 \%)$ in $0.05 \mathrm{M}$ cacodylate buffer $\mathrm{pH} 7.2$ for a minimum of two hours at room temperature. To facilitate penetration of the fixative, the samples were subjected to vacuum (ca. 0.1 mm Hg) for 10-15 min. Subsequently, the samples were dehydrated in an increasing series of ethanol concentration $(30 \%, 50 \%, 70 \%, 90 \%$, and 3 times in $100 \%$ for 30 minutes in each step), pre-infiltrated (8-12 hours in a mixture of Technovit acrylic resin / 1: 1 absolute ethanol), infiltrated in the pure resin for one night and embedded in plastic form and polymerized at room temperature, following the manufacturer instructions. To assist in the infiltration of the resin in the material, the microtubes containing the samples and the resin were subjected for short periods (between 5 to 10 minutes) to a vacuum pump and centrifugation (10,000 revolutions per minute). After polymerization, cross sections of 5-8 $\mu \mathrm{m}$ were made, using the Leica RM2355 rotary microtome and stained with $0.05 \%$ toluidine blue in phosphate-citrate buffer, pH 4.5 (SAKAI, 1973). Tissue sections were mounted on Entellan ${ }^{\circledR}$ and slides analyzed using the Zeiss Axioskop photomicroscope; images were registered digitally.

\section{ROS detection}

To detect $\mathrm{H}_{2} \mathrm{O}_{2}$, the leaves were collected and immediately immersed in freshly prepared 1 $\mathrm{mg} \mathrm{ml}^{-} 3,3^{\prime}$ diaminobenzidine (DAB) $\left(\right.$ TermoFisher $\left.^{\circledR}\right)$ in PBS solution, adjusted to $\mathrm{pH} 4.0$ with $\mathrm{HCl}$. Fragments of leaves containing the lesions of ClCSV and CoRSV were immersed and infiltrated for 2-3 hours within $50 \mathrm{ml}$ Falcon Tubes in the dark. The samples were analyzed with a digital microscope Hirox where the images were registered digitally.

\section{RESULTS AND DISCUSSION}

\section{Control uninfected tissues}

In coffee leaves, as in previous descriptions (DEDECCA, 1957) the epidermis is covered by a thin cuticle and composed of cells with variable sizes, however, the cells on the abaxial side are smaller than those on the adaxial face. It is hypoestomatic and presents dorsiventral mesophyll that consists of a palisade parenchyma layer of elongated cells that accumulate phenolic 
compounds, juxtaposed and with dense material accumulated. The spongy parenchyma presents braciform cells with 6-8 layers of cells, spaced apart, forming the free spaces (Figure 1A).
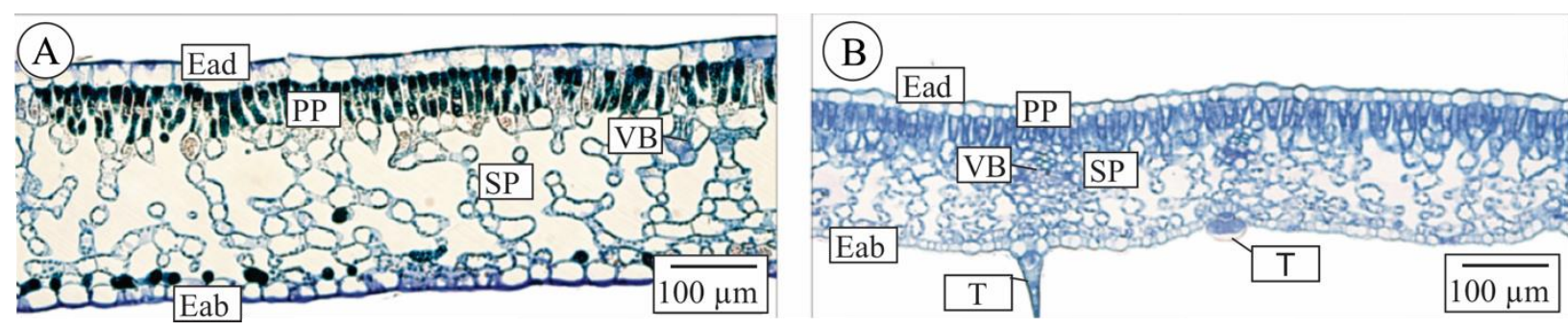

Figure 1. Light micrographs of toluidine blue-stained, cross sections of control leaves (healthy) stained with toluidine blue. A. Coffea arabica leaf. B. Clerodendrum thomsoniae. Eababaxial epidermis; Ead- adaxial epidermis; VB- vascular bundle; SP- Spongy parenchyma; PP- palisade parenchyma; T-trichome.

Concerning bleeding glory bower leaf anatomy, present observations demonstrate that the leaf is anphistomatic composed by an epidermis of the adaxial surface, formed by a layer of flattened cells and on the abaxial surface, cells of reduced size in relation to those of the adaxial surface. The leaf has glandular and non-glandular trichomes on the abaxial surface. The mesophyll is dorsiventral with a palisade layer of cells and five to six layers of spongy parenchyma (Figure 1B).

These findings are essentially similar to those reported by Herman (1998) on leaves of $C$. thomsoniae.

\section{Infected Tissues}

In the bleeding glory bower leaves, the lesions had a central necrotic region surrounded by a chlorotic halo (Figure 2A, 2B). Light microscopy analysis reveals that the mesophyll is destroyed in the necrotic regions (Figure 2C), which appear depressed along with the lesion (Figure 2E). The hypertrophy of cells of the spongy parenchyma is clearly observed in the region corresponding to the chlorotic halo (Figures 2D, E). 

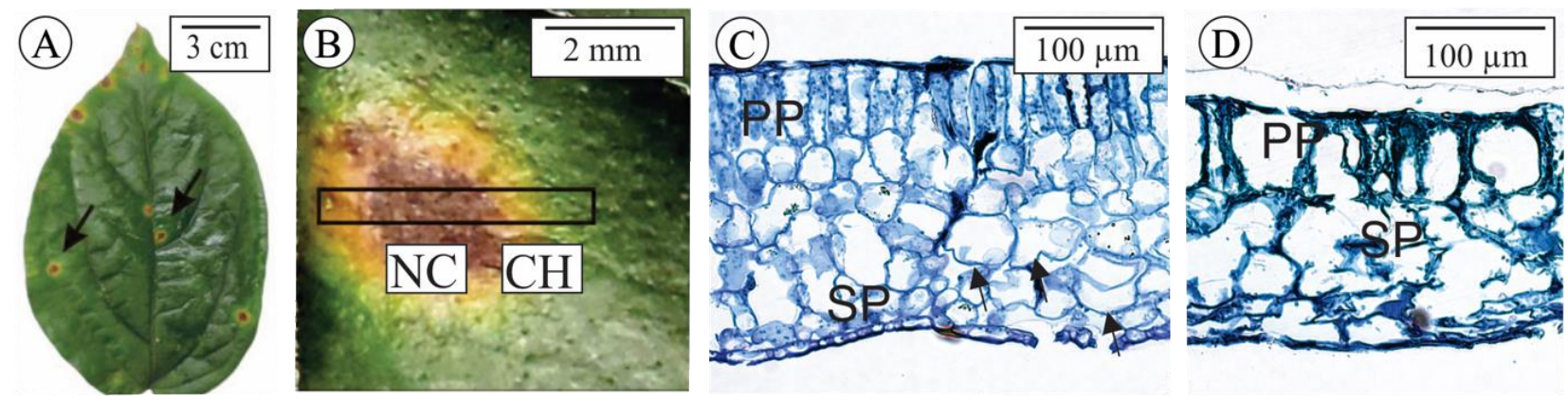

(E)

Necrotic Center $500 \mu \mathrm{m}$

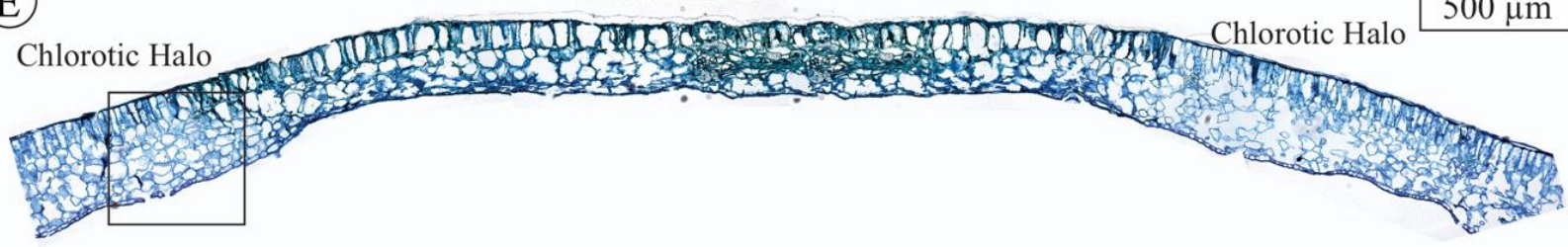

Figure 2. Clerodendrum thomsoniae leaf lesions caused by Clerodendrum chlorotic spot virus (ClCSV) infection. Sections stained with toluidine blue (C, D, E). A. Overview of the ClCSV-infected leaf exhibiting the chlorotic lesions with a necrotic center; B. detail of a typical lesion. The rectangle indicates the sectioned region depicted in E; C. cross section chlorotic halo corresponding to the square in E. Arrows indicate the hypertrophied spongy parenchyma cells; D. cross section of part of the necrotic center, revealing necrotic cells and disorganized tissue; E. cross section of the lesion, corresponding to the region indicated in B, showing the necrotic center flanked by the chlorotic halo. $\mathrm{CH}$ - chlorotic halo; NC- necrotic center; PP- palisade parenchyma; SPspongy parenchyma.

In the coffee leaf blade with ringspots caused by CoRSV infection, the lesions appear as circular chlorotic spots, in some cases accompanying the ribs, which, in an advanced stage, may develop necrosis in the center (Figure 3A, 3B). Analyzes under a light microscope, the necrotic center of mature lesion shows palisade parenchymal cells with reduced size and dense, besides collapsed spongy parenchyma (Figure 3D). In the border of the lesion, between the injured area and the leaf blade without symptoms, hypertrophy of the cells of the spongy parenchyma was clearly noticed (Figure 3C).

The histopathological changes in lesions caused by CICSV and CoRSV, respectively in $C$. thomsonae and coffee leaves, are basically similar to the previously reported for another dichorhavirus, CiLV-N (MARQUES et al., 2010), and also agree with preliminary studies reported by Gomes et al. (2010), respectively for CoRSV and ClCSV (see schematic representation in Figure 4). Mature lesions have a depressed necrotic center with necrosed palisade parenchymal cells and 
disorganized spongy parenchyma (Figures 2,3 ). In the surrounding chlorotic halo region, leaf blades are thicker, and remarkably many spongy parenchyma cells appear hypertrophied. It is worthy to mention that lesions caused by Citrus leprosis virus C, a Cilevirus, might become more expanded than lesions caused by nuclear BTVs, and usually have concentric gummy rings permeating the large chlorotic halo (MARQUES et al., 2007). The formation of the gummy ducts that accumulate mucilage, in the vascular bundles, observed in lesions caused by CiLV-N and CiLV-C (MARQUES et al., 2007; 2010) was absent in lesions caused by ClCSV and CoRSV. It is likely that such changes are a more specific response associated with Citrus spp. to pathogen invasion (GEDALOVICH \& FAHN, 1988).
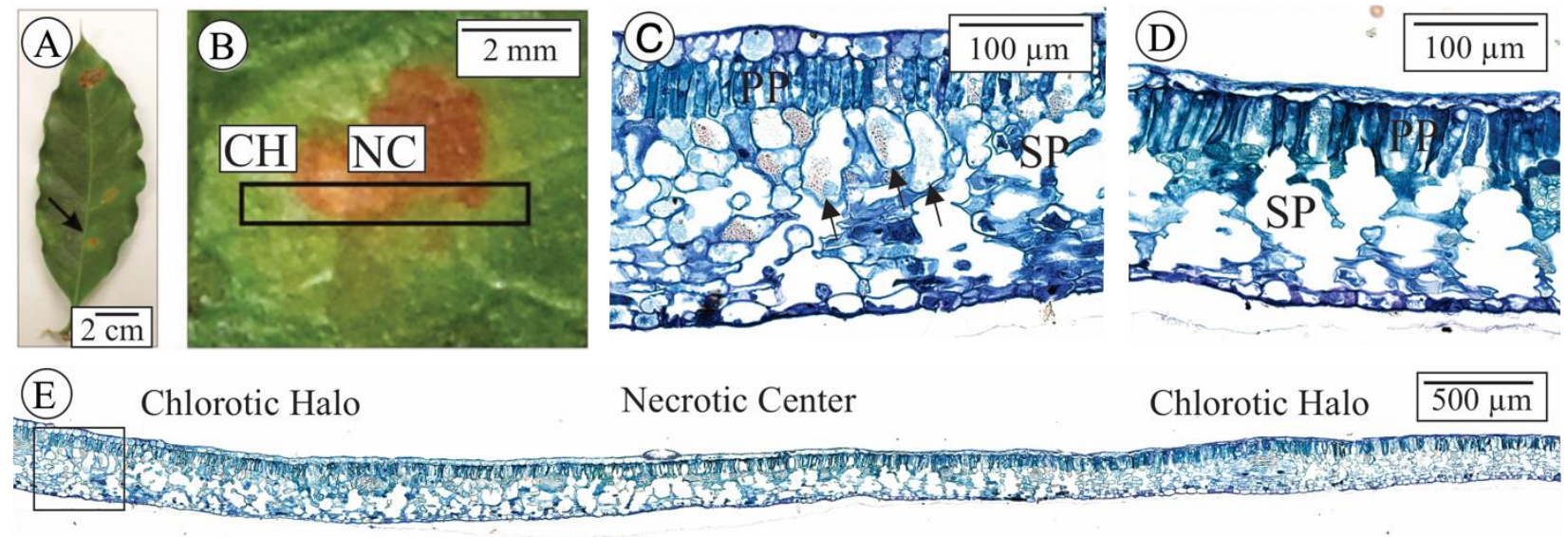

Figure 3. Lesions caused by coffee ringspot virus (CoRSV) on Coffea arabica leaves. Sections stained with toluidine blue (C, D, E). A. An overview of leaf with lesions; B. detail of a typical lesion. The rectangle corresponds to the section as shown in E; C. detail of the border of the chlorotic halo of the lesion, indicated by the square in E; arrows indicate hypertrophied cells in the spongy parenchyma (SP); D. part of the depressed necrotic center, formed by necrotic and dense palisade parenchyma (PP) cells, and disorganized SP; E. cross section along the mid-lesion clearly revealing its different regions. $\mathrm{CH}-$ chlorotic region; NC- necrotic center. 


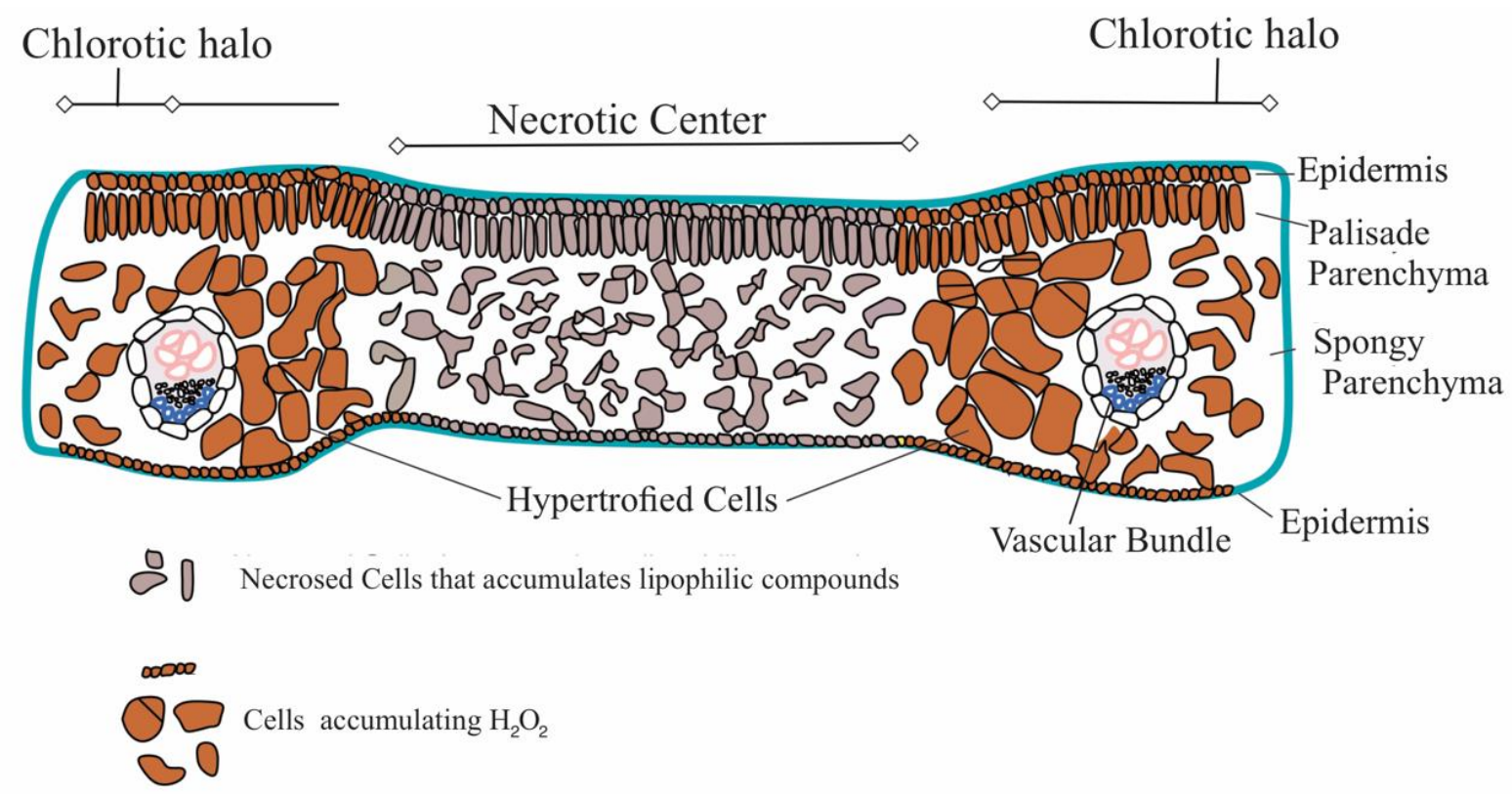

Figure 4. Schematic model of injuries caused by Coffee ringspot and Clerodendrum chlorotic spot dichorhaviruses. Central depressed region is formed by necrosed palisade parenchymal cells and collapsed spongy parenchyma. In most of the surrounding chlorotic halo, hypertrophied spongy parenchyma cells are present, which accumulate $\mathrm{H}_{2} \mathrm{O}_{2}$.

Staining sections with DAB indicated that the chlorotic halo accumulates hydrogen peroxide in both lesions, resulted by infection with CICSV (Figure 5A-B) and CoRSV (Figure 5CD). DAB reaction seems to be restrained to the chlorotic halo and its reaction diminishes and disappears in the lesion boarders. $\mathrm{H}_{2} \mathrm{O}_{2}$ is a reactive oxygen species - $\mathrm{ROS}$ and its production is associated to molecular plant responses to pathogen recognition or signaling event of a whole biochemical pathway cascade in a plant response to pathogens actions (DÍAZ-VIVANCOS et al. 2008; HERNÁNDEZ et al., 2016). 


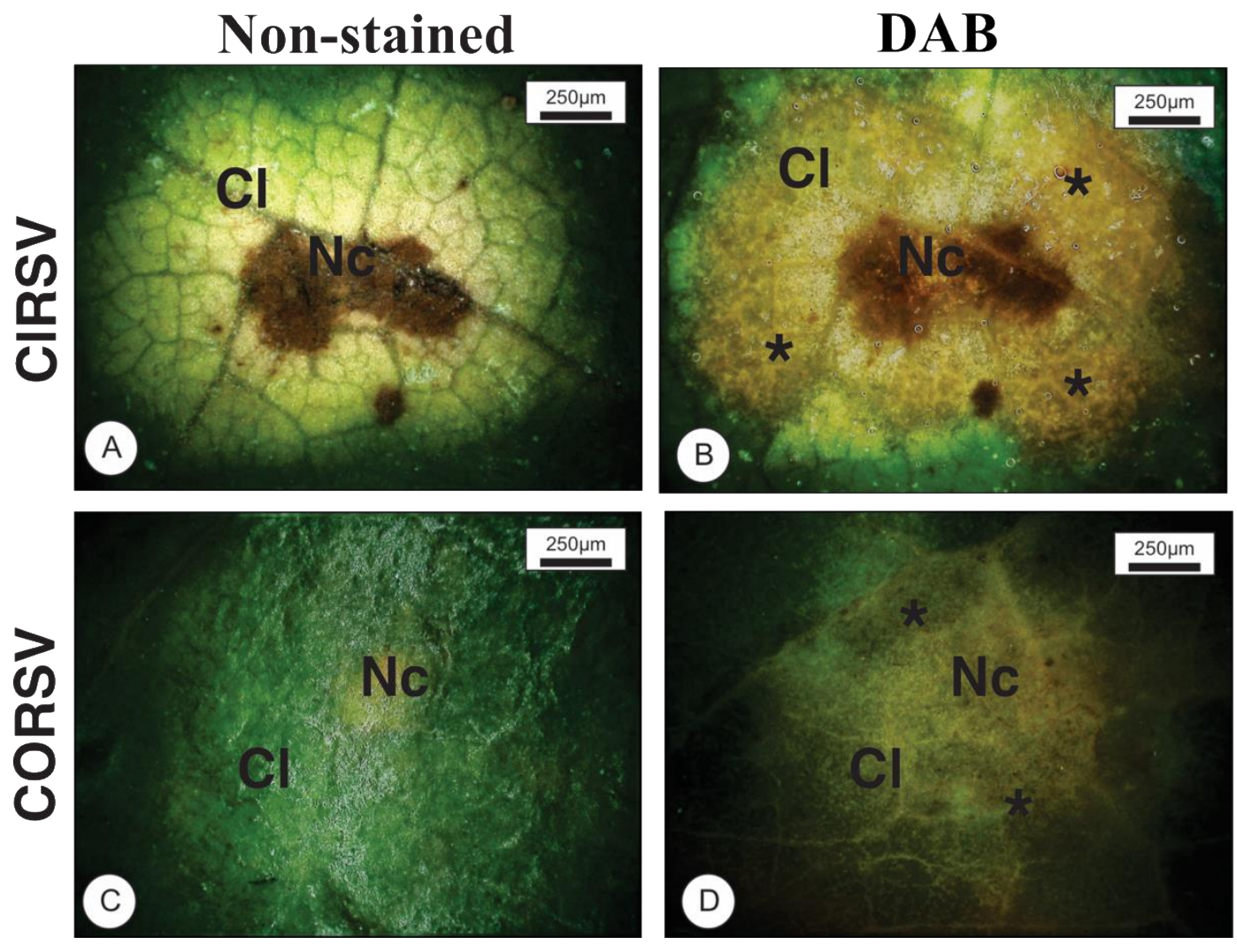

Figure 5. Histochemical test to detect hydrogen peroxide $\left(\mathrm{H}_{2} \mathrm{O}_{2}\right)$ by 3'3-diaminobenzidine (DAB). A. Clerodendrum thomsoniae leaf lesion caused by ClCSV infection. B. brown precipitate indicate $\left(\mathrm{H}_{2} \mathrm{O}_{2}\right)$ accumulation in the chlorotic area. C. Coffea arabica leaf lesion caused by CoRSV infection. D. brown precipitate indicate $\left(\mathrm{H}_{2} \mathrm{O}_{2}\right)$ accumulation in the chlorotic area. Nc- Necrotic center. Cl- Chlorotic halo.

Detection of hydrogen peroxide within the chlorotic region of lesions is an important information that can shed light on the possible signaling effect of defense mechanisms of infected tissues in the chlorotic region. Recently, it was described that CiLV-C infection triggers ROS burst and cell death (ARENA et al., 2020). Based on our observations, we suggest that the ROS in these two examined Dichorhavirus cases may have a different role, as inducing the cell hypertrophy in spongy parenchyma in the chlorotic halo. It seems to be an intriguing question to be answered by further molecular analysis.

\section{CONCLUSION}

This study provided pieces of evidence that lesions caused by two distinct Dichorhaviruses have histopathological patterns similar to those previously reported for another virus of the same 
genus, CiLV-N. The presence of a center with necrosed cells surrounded by and a chlorotic halo that accumulate $\mathrm{H}_{2} \mathrm{O}_{2}$ and have hypertrophied cells. These results demonstrate that lesions caused by viruses transmitted by Brevipalpus mites can present specific structural patterns, independently from its diversity of symptoms.

\section{ACKNOWLEDGEMENTS}

This research was funded by São Paulo Research Foundation (Fundação de Apoio à Pesquisa do Estado de São Paulo - FAPESP), grants 2014/08458-9 and 2017/50222-0. GMF and ADT have scholarships from FAPESP, respectively 2016/10799-4 and 2018/12252-8. JPRM have scholarship from Coordination for the Improvement of Higher Education Personnel (Coordenação de Aperfeiçoamento de Pessoal de Nível Superior - CAPES) - Finance Code 001.

\section{REFERENCES}

APEZZATTO-DA-GLÓRIA, B., MARQUES, J. P. R., FREITAS-ASTÚA, J. \& KITAJIMA, E. W. 2007. Análise morfológica da evolução das lesões lepróticas foliares de Citrus sinensis (L.) Osbeck 'Pera'. Revista Brasileira de Biociências. Porto Alegre, vol. 5, supl.:879-881.

ARENA G. D., RAMOS-GONZÁLEZ, P. L., FALK B.W., CASTEEL C. L., FREITAS-ASTÚA J., MACHADO M. A. 2020. Plant immune system activation upon Citrus leprosis virus c infection is mimicked by the ectopic expression of the P61 viral protein. Frontiers in Plant Science, Parkville, Doi: 10.3389/fpls.2020.01188

BASSANEZI, R. B. 2018. Mudanças na citricultura e o controle do ácaro da leprose. Citricultura Atual, Cordeirópolis, p. 21-24.

BASTIANEL, M.; FREITAS-ASTUA, J.; KITAJIMA, E. W.; MACHADO, M. A. 2006. The Citrus leprosis pathosystem. Summa Phytopathologica, Botucatu, vol 32, p. 211-220.

CALEGARIO, R. F., GARITA, L., SALAROLI, R. B., KITAJIMA, E. W. 2011. Immunofluorescence studies on the distribution of Citrus leprosis virus $\mathrm{C}$ (CiLV-C) in different hosts. Res. XIII Congresso Soc. Bras. Microscopia e Microanálise, 2011, BúziosRJ. Soc. Bras. Microscopia e Microanálise. v. 1.

CHABI-JESUS, C., RAMOS-GONZÁLEZ, PL，TASSI，A. D, GUERRA-PERAZA，O, KITAJIMA, E. W., HARAKAVA, R., BESERRA J. R., J.E.A., SALAROLI, R. B., FREITASASTUA, J. 2018. Identification and characterization of Citrus chlorotic spot virus, a new dichorhavirus associated with Citrus leprosis-like symptoms. Plant Disease, St. Paul, vol. 102 , p.1588-1598.

CHAGAS, C. M. 1978. Mancha anular do cafeeiro: transmissibilidade, identificação do vector e aspectos anátomo-patológicos da espécie Coffea arabica L. infectada pela moléstia. Tese Doutorado, USP, 132p.

COOK, G., KIRKMAN, W., CLASE, R., STEYN, C., BASSON, E., FOURIE, P.H., MOORE, S. D., GROUT, T. G., CARSTENS, E., HATTINGH, V. 2019. Orchid fleck associated with the 
first case of citrus leprosis-N in South Africa. European Journal Plant Pathology, London, vol. 155, p. 1373-1379.

DEDECCA, D. M. 1957. Anatomia e Desenvolvimento ontogenético de Coffea arabica L. var. typica Cramer. Bragantia, Campinas, vol. 16: 315-366.

DÍAZ-VIVANCOS, P.; CLEMENTE-MORENO, M.J.; RUBIO, M.; OLMOS, E.; GARCÍA, J. A.; MART'INEZ-GÓMEZ, P.; HERNÁNDEZ, P. A. 2008. Alteration in the chloroplastic metabolism leads to ROS accumulation in pea plants in response to plum pox virus Journal of Experimental Botany, Lancaster, vol. 59, n. 8, p. 2147-2160.

DIETZGEN, R. G.; KUHN, J. H.; CLAWSON, A. N.; FREITAS-ASTÚA, J.; GOODIN, M. M.; KITAJIMA, E. W.; KONDO, H.; WETZEL, T.; WHITFIELD, A. E. 2014. Dichorhavirus: a proposed new genus for Brevipalpus mite-transmitted, nuclear, bacilliform, bipartite, negativestrand RNA plant viruses. Archives in Virology, Viena, vol. 159, p. 607-19.

DIETZGEN, R. G. FREITAS-ASTÚA, J., CHABI-JESUS, C., RAMOS-GONZÁLEZ, P. L., GOODIN, M.M., KONDO, H., TASSI, A.D., KITAJIMA, E.W. 2018. Dichorhaviruses in their host plants and mite vectors. Advances in Virus Research, New York, vol. 102, doi.org/10.1016/bs.aivir.2018.06.001.

FAWCETT, H. S. 1911. Scaly bark or nail head rust of citrus. Florida Agricultural Experimental Station Bulletin, Gainesville, vol. 106. 41p.

FREITAS-ASTÚA, J., RAMOS-GONZÁLEZ, P. L., ARENA, G. D., TASSI, A. D., KITAJIMA, E.W. 2018. Brevipalus-transmitted viruses: parallelism beyond a common vector or convergent evolution of distantly related pathogens? Current Opinion in Virology, Amsterdam. DOI 10.1016/j.coviro.2018.07.010

FREZZI M. S. 1940. La lepra explosive del naranjo. Investigaciones realizadas por el laboratorio de patologia de Bella Vista (Corrientes). Boletin Fruticultura e Horticultura, Buenos Aires, n.5, p. 1-16.

GEDALOVICH, E.; FAHN, A. 1985.The development and ultrastructure of gum ducts in Citrus plants formed as a result of brown-rot gummosis. Protoplasma, Viena, v.127, p.73-81.

GOMES, R. T.; KITAJIMA, E.W.; TANAKA, F. A. O.; MARQUES, J. P. R.; APPEZZATO-DAGLÓRIA, B. 2010. Anatomia de lesões foliares causadas pelo vírus da Mancha Clorótica do Clerodendrum, transmitido pelo ácaro Brevipalpus phoenicis em diferentes espécies. Summa Phytopathologica, Jaguariúna, v.36, n.4, p.291-297.

HERMAN, P. P. J. 1998. The leaf anatomy of two Clerodendron species (Verbenaceae). South African Journal of Botany, Scottsville, vol. 642, p. 46-249.

HERNÁNDEZ, J. A.; GULLNER, G.; CLEMENTE-MORENO, M.L.; KÜNSTLER, A.; SILLA JUHÁSZ S.; DÍAZ-VIVANCOS, P.; KIRÁLY, K. 2016. Oxidative stress and antioxidative responses in plant-virus interactions. Physiological and Molecular Plant Pathology, London, vol. 94, p. 134-148.

KITAJIMA, E. W., CHAGAS, C. M. \& RODRIGUES, J. C. V. 2003. Brevipalpus-transmitted plant virus and virus-like diseases: cytopathology and some recent cases. Experimental and Applied Acarology, Amsterdam, vol. 30, p.135-160.

KITAJIMA, E. W., RODRIGUES, J. C. V., FREITAS-ASTUA, J. 2010. An annotated list of ornamentals naturally found infected by Brevipalpus mite-transmitted viruses. Scientia Agricola, Piracicaba, vol. 67, n.3, p.348-371.

KITAJIMA, E. W., CHAGAS, C.M., BRAGHINI, M. T., FAZUOLI, L. C., LOCALI-FABRIS, E.C., SALAROLI, R.B. 2011. Natural infection of several Coffea species and hybrids 
and Psilanthus ebracteolatus by the Coffee ringspot virus (CoRSV). Scientia Agricola, Piracicaba, vol. 68, p. 503-507.

LOCALI-FABRIS, E. C.; FREITAS-ASTÚA, J.; MACHADO, M. A. 2011. Genus Cilevirus. In: Virus Taxonomy - Ninth Report of the International Committee on Taxonomy of Viruses. KING, A.; ADAMS, M.; CARSTENS, E.; LEFKOWITZ, E., Eds.; Elsevier/Avademic Press: London, United Kingdom, p. 1139-1142.

MARQUES, J. P. R., FREITAS-ASTUA, J., KITAJIMA, E. W. \& APEZZATTO DA GLÓRIA, B. 2007. Lesões foliares e de ramos de laranjeira-doce causadas pela leprose-dos-citros. Pesquisa Agropecuária Brasileira, Brasília, vol. 42, n. 11, p. 1531-1536.

MARQUES, J. P. R., KITAJIMA, E. W., FREITAS-ASTÚA, J. \& APEZZATTO-DA-GLORIA, B. 2010. Comparative morphoanatomical studies of the lesions caused by Citrus leprosis virus on sweet orange. Anais da Academia Brasileira de Ciências, Rio de Janeiro, 82: 501-511

RAMOS-GONZÁLEZ. P. $\quad$ L., CHABI-JESUS， C., GUERRA-PERAZA, O., TASSI, A.D., KITAJIMA, E.W., HARAKAVA, R., SALAROLI, R.B., FREITAS-ASTÚA, J. 2017. Citrus leprosis virus N: a new dichorhavirus causing Citrus leprosis disease. Phytopathology, St. Paul, vol. 107, p. 963-976.

RAMOS-GONZÁLEZ, P. L.; CHABI-JESUS, C.; ARENA, G. D.; TASSI, A. D.; KITAJIMA, E. W.; FREITAS-ASTÚA. J. 2018a. Leprosis de los cítricos: una enfermedad multietiológica singular Citricos em las Americas, Havana, 1: 4-19. (in Spanish and English)

RAMOS-GONZÁLEZ, P. L.; CHABI-JESUS, C.; BANGUELA-CASTILLO, A.; TASSI, A. D.; RODRIGUES, M. C.; KITAJIMA, E. W.; HARAKAVA, R.; FREITAS-ASTÚA, J. $2018 \mathrm{~b}$. Unveiling the complete genome sequence of Clerodendrum chlorotic spot virus, a putative Dichorhavirus infecting ornamental plants. Archives of Virology, Berlin, 163: 2519-2524.

ROY, A.; CHOUDHARY, N.; GUILLERMO, L. M.; SHAO, J.; GOVINDARAJULU, A.; ACHOR, D.; WEI, G.; PICTON, D. D.; LEVY, L.; NAKHLA, M. K.; HARTUNG, J. S.; BRLANSKY, R. H.A. 2013. Novel virus of the genus Cilevirus causing symptoms similar to citrus leprosis. Phytopathology, St. Paul, vol. 103, p. 488-500.

ROY, A.; STONE, A. L.; SHAO, J.; OTERO-COLINA, G.; WEI, G.; CHOUDHARY, N.; ACHOR, D.; LEVY, L.; NAKHLA, M.K.; HARTUNG, J. S.; SCHNEIDER, W. L.; BRLANSKY, R. H. 2015. Identification and molecular characterization of nuclear citrus leprosis virus, a member of the proposed Dichorhavirus genus infecting multiple citrus species in Mexico. Phytopathology, St. Paul, vol. 105, p. 564-75.

SAKAI, W. S. 1973. Simple method for differential staining of paraffin embedded plant 396 material using toluidine blue O. Stain Technology, Baltimore, vol. 48, n. 5, p. 247-249. 